Ethiopian Journal of Environmental Studies \& Management 8(3): 272 - 282, 2015.

ISSN:1998-0507

doi: http://dx.doi.org/10.4314/ejesm.v8i3.4

Submitted: January 10, 2015

Accepted: March 24, 2015

\title{
SURVEY OF GROUND DWELLING ARTHROPODS ASSOCIATED WITH TWO HABITAT TYPES IN THE JOS MUSEUM ZOOLOGICAL GARDEN JOS PLATEAU STATE, NORTH CENTRAL NIGERIA
}

\author{
*NJILA, H.L. ${ }^{1}$ AND HADI, S.M. ${ }^{2}$ \\ ${ }^{1}$ Department of Science Laboratory Technology, University of Jos, P.M.B. 2084, Jos, Plateau \\ State, Nigeria \\ ${ }^{2}$ Department of Zoology,University of Jos, P.M.B. 2084, Jos, Plateau State, Nigeria
}

\begin{abstract}
Little is known about the species composition and ecology of ground dwelling arthropods of Zoological Gardens. Thus, this study was aimed to investigate the species abundance and diversity of ground dwelling arthropods associated with Gallery forest and Rocky outcrop of the Jos Museum Zoological Garden Jos Plateau State, North central Nigeria. Arthropods were collected using Pitfall traps during the raining season of June-July, 2013. A total of 500 arthropods belonging to 6 Classes, 11 Orders, 12 Families, 14 Genera and 14 Species were collected. Out of which 130 arthropods individuals representing 26\% of the total were collected from Gallery forest, whereas 370 arthropods individual representing $74 \%$ were collected from Rocky outcrop. There is a significant difference in the mean abundance of species of ground dwelling arthropods collected from both habitats. There is no significant difference in the mean abundance of ground dwelling arthropods in relation to taxa. The diversity and distribution of arthropods taxa depicted 73\% Insecta and 64.4\% Hymenoptera as the most abundant taxa. The Shannon-Weiner diversity index $(H)$ differs significantly between the two habitat types. The Gallery forest had the highest diversity index of 2.2140 and Rocky outcrop had the lowest diversity index of 0.9038. Food availability and vegetation cover were found to be critical to arthropods species abundance and diversity. This is a pointer to the usefulness of vegetation and food as key resources for ground dwelling arthropods. It is therefore recommended that adequate protection of the garden be carried out to curd anthropogenic activities.
\end{abstract}

Key Words: Arthropods, Habitats, Gallery forest, Rocky outcrop and Zoological garden

\section{Introduction}

Arthropod are the most successful and diverse group of animals. More than $80 \%$ of the described living animal's species are arthropods of the phylum Arthropoda which is the largest in the animal kingdom and comprise of more than one million species (Franke, 2003). They are common throughout marine, freshwater, terrestrial and even aerial environments (Thanukos,
2007). However there are several other families in the phylum Arthropoda which are important to the forest ecosystem (Basset, 2001). Entomologists have focused their attention on biodiversity of arthropods as a tool for conservation and this has received increasing attention (Noss, 1990).Arthropods are important in below ground processes through the alteration of the physical and chemical environment and 
through their effects on plants microorganisms and other soil organisms (Motohiro, 2001).Arthropods in both forest and surrounding farm lands serve as food for Birds, Predatory insect and other vertebrates, plant pollinators, diseases vectors of mammals, biological control agents, and biotic indicators of health of the forest (Basset, 2001).The continuous removal of forests for various agricultural and industrial purposes has caused the loss and degradation of the primary tropical forests, leaving only man-made ones. This destruction causes extinction or loss of richness for those species whose habitats have been altered by man (Adebayo, 1995).Studies of arthropod responses to ecological change can enhance man's understanding of the effects of human disturbance and landscape modification on the terrestrial ecosystem. In addition, species diversity can be measured using the number of species present and their relative abundance (Watt et al., 2002).Currently, little is known about the species composition and ecology of ground dwelling arthropods of Zoological Garden.

This study was carried out to generate a species checklist of ground dwelling arthropods of Gallery forest and Rocky outcrop of Jos Museum Zoological Garden the second oldest Museum in Nigeria where no studies have been carried out. More importantly, the species checklist will provide a template on which to overlay an examination of species diversity of ground dwelling arthropods that may be associated with similar habitats elsewhere.

\section{Methodology}

\section{Study Area}

The Jos Museum was founded in December, 1955 and was approved in June 1960 when the Zoological Society of Nigeria was formed to manage it. Jos Museum is the second oldest museum in Nigeria, after the small museum at Esie, near Ilorin, which was opened in 1945. For many years Jos was the headquarters of the
Federal Department of Antiquities until this was eventually transferred to Lagos. It is the second largest museum in the country offering a wide range of exhibits and facilities for visitors. It is also the principal research station for the Department. The study was conducted within the Gallery forest and Rocky outcrop of the museum. It is located in the heart of the cityof Jos, Plateau State, North-Central Nigeria and found on longitude 9 54' 51"North and latitude $8^{\circ}$ 53' 9"East (Figure 1).Though situated in the tropical zone, a higher altitude means that Jos has a near temperate climate with an average temperature of between 18 and $22^{\circ} \mathrm{C}$. Harmattan winds cause the coldest weather between December and February. The warmest temperatures usually occur in the dry season months of March and April. The mean annual rainfall varies from $131.75 \mathrm{~cm}$ (52 in) in the southern part to $146 \mathrm{~cm}$ (57 in) on the Plateau. The highest rainfall is recorded during the wet season months of July and August. The Jos Plateau is the source of many rivers in northern Nigeria including the Kaduna, Gongola, Hadejia and Yobe rivers (Ajakpo and Okonkwo, 1984).In line with the rainfall distribution, Plateau State falls largely within the northern guinea savannah zone which consists mainly of short trees, grasses and the Plateau type of mosaic vegetation. Fringing woodlands or gallery forests can be found along some river valleys. The unique physical features of Plateau State are its high relief, especially in the north, and its geological history. The high relief, or more appropriately, the Jos Plateau, provides a hydrological Centre for many rivers in northern Nigeria and confers on the northern part of the state a cool climate suitable for livestock rearing and growing of exotic crops. The process of formation of its high relief makes Plateau State one of the mineral rich states in the country (Ajakpo and Okonkwo, 1984). 


\section{Sampling Techniques}

The pit fall traps were used to sample arthropods within the Gallery forest and Rocky outcrop of the Museum Zoological Garden during the raining season of JuneJuly 2013. In each habitat, a total of twenty pit fall traps were randomly placed. The sampling design involved placing a trap at a distance of 50meters away from each other for a period of twenty four (24) hours along a transect in each habitat type (Van den Bergh, 1992). The objective is to give all arthropods an equal chance of being trapped. Arthropods were harvested after 24hours. Plants debris was removed and arthropods collected were preserved in $70 \%$ alcohol, 10\% glycerin and 20\% distilled water (Sutherland, 1997)

\section{Identification and Quantification of} Arthropods

Each labelled sample bottle was emptied into a Petri- dish, observed, screened out and quantified. The arthropods were then identified, grouped and classified into classes, order, families, genus and species using coloured atlas and identification keys provided by Castner (2000), Shattuck (2000) and Skaife et al. (1979).

\section{Statistical Analysis}

The data was analyzed using R-Console Software version 2.9.2. The Welch Two Sample t-test was used to compare the mean abundance of ground dwelling arthropods between Gallery forest and Rocky outcrop habitats. One-way analysis of variance (ANOVA) was used to compare the mean abundance of ground dwelling arthropods in relation to the classes, orders, and families respectively. Significant level was achieved if $\mathrm{P}<0.05$.

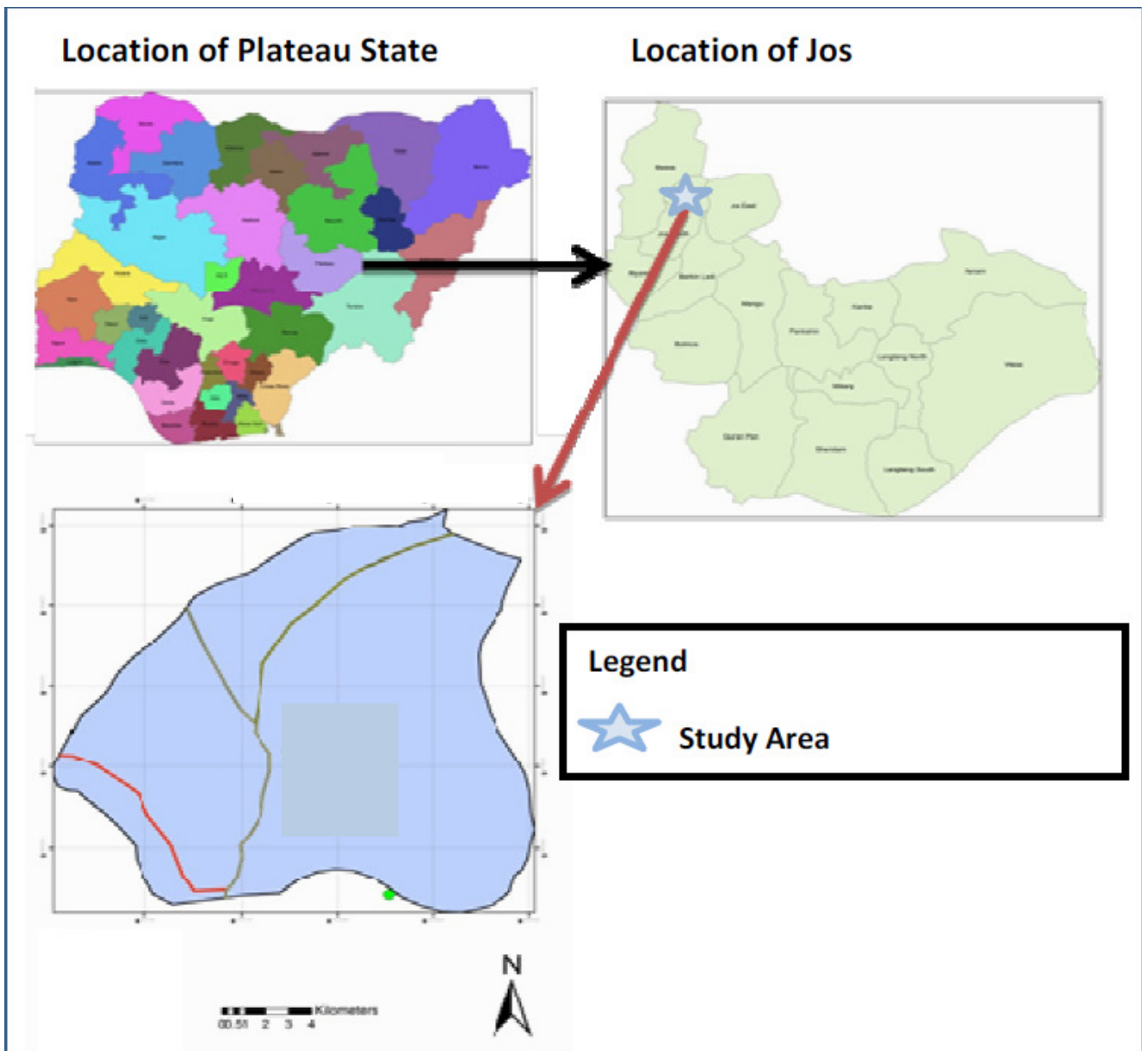

Figure 3: Map of Plateau State, Nigeria showing location of the study area 


\section{Species Diversity Index}

Arthropod species diversity was calculated using the Shannon-Weiner diversity index $(\mathrm{H})$ (Shannon and Weiner, 1963):

$$
H=-\sum_{i=1}^{S} P_{i} \ln P_{i}
$$

Where:

$H$ is the diversity index

$P i$ is the proportion of individual species

$S$ is the total number of species in the habitat and

$i$ is the proportion of $S$ species

\section{Results}

Species Checklist of Ground Dwelling Arthropods

Species checklist of ground dwelling arthropods generated at the end of the study is shown in Table 1. A total of 500 arthropods belonging to 6 Classes, 11 Orders, 12 Families, 14 Genera and 14 Species were collected and identified (Table 1). There is a significant difference $\left(\mathrm{F}_{27}=1\right.$. 252, Adjusted R- Squared $=$ $0.0679, \mathrm{P}=0.3031$ ) in the mean abundance of species of arthropods (Figure1). Solenopsis invicta (Coleoptera: Formicidea), Archispirostreptu sgigas (Spirostreptida: Spirostreptidae) and Cicindela ocellata (Coleoptera: Carabidae) were the most abundant species of arthropods identified. Conversely, the least abundant species were Calosoma scrutator (Coleoptera: Carabidae), Paederus species (Coleoptera: Staphylindae) and Gryllus campestrus (Orthoptera: Gryllidae) (Figure $1)$.

There is a significant difference in the mean abundance of ground dwelling arthropods between the Gallery Forest and Rocky outcrop of the Jos Museum
Zoological Garden (Welch Two Sample ttest: $\mathrm{t}=-2.053$, df $=27.605, \mathrm{P}=0.04966$ ) as shown in Figure 2. Whereas 130 individuals representing $26.00 \%$ of the total were collected from Gallery forest, 370 representing $74.00 \%$ were collected from Rocky outcrop as shown in (Table 1).

The breakdown of this result shows that a total of 13 species of ground dwelling arthropods were collected from Gallery forest (Table 1). The comparison in the mean abundance of species of arthropods shows a significant difference $\left(\mathrm{F}_{27}=1.252\right.$, Adjusted R- Squared $=$ $0.0679, \mathrm{P}=0.3031$ ) in the mean abundance of species of arthropods in the Gallery forest. S. gigantea, A. gigas and L. reclusa are the most abundant species of ground dwelling arthropods collected from the Gallery forest. Conversely, the least abundant species were Paedarus species, G. campestrus and Blatella lituricollis (Table 1).

A total of 10 Species of ground dwelling arthropods were collected from Rocky outcrop (Table 1). The comparison of mean abundance of species of ground dwelling arthropods shows significant difference $\left(\mathrm{F}_{17}=1.745\right.$, Adjusted $\mathrm{R}$ Squared $=0.2051, \mathrm{P}=0.1543$ ), in the mean abundance of species in the Rocky outcrop. S. invicta, A. gigas and $I$. purpureus were the most abundant species collected from Rocky outcrop.

Conversely, B. lituricollis (Blattodae: Blatella),

Solenopsis molesta(Hymenoptera: Formicidae) and Calosoma scrutator (Coleoptera: Carabidae) were the least abundant species of ground dwelling arthropods collected from Rocky outcrop (Table 1). 
Table 1: Species Checklist of Ground Dwelling Arthropods Collected from Gallery Forest and Rocky Outcrop of the Jos Museum Zoological Garden

\begin{tabular}{|c|c|c|c|c|c|c|c|c|}
\hline Class & Order & Family & Common Name & Species & GF & $\mathrm{RO}$ & Total & $\begin{array}{l}\text { Percent } \\
(\%)\end{array}$ \\
\hline \multirow[t]{2}{*}{ Arachnida } & Araneae & Pholcidae & Daddy long leg & Pholcus phalangoides & 15 & 4 & 19 & 3.80 \\
\hline & & Sicariidae & Brown recluse spider & Loxosceles reclusa & 17 & 7 & 24 & 4.80 \\
\hline \multirow[t]{9}{*}{ Insecta } & Coleoptera & Carabidae & Tiger beetle & Cicindela ocellata & 15 & 11 & 26 & 5.20 \\
\hline & & & Ground beetle & Calosoma scrutator & - & 2 & 2 & 0.40 \\
\hline & & Staphylinidae & Rove beetle & Paederus species & 2 & - & 2 & 0.40 \\
\hline & Orthoptera & Gryllidae & Field cricket & Gryllus campestrus & 1 & - & 1 & 0.20 \\
\hline & Blattodea & Blatellidae & False German cockroach & Blatella lituricollis & 1 & 4 & 5 & 1.00 \\
\hline & Dermaptera & Forficulidae & Earwig & Corixa puntata & 4 & - & 4 & 0.80 \\
\hline & Hymenoptera & Formicidae & Fire ant & Solenopsis invicta & - & 286 & 286 & 57.20 \\
\hline & & & Black carpenter ant & Camponotus pennsylvanicus & 3 & 5 & 8 & 1.60 \\
\hline & & & Thief ant & Solenopsis molesta & - & 3 & 3 & 0.60 \\
\hline Chilopoda & Geophilomorpha & Scolopendridae & Giant centipede & Scolopendra gigantean & 25 & - & 25 & 5.00 \\
\hline Diplopoda & Spirostreptida & Spirostreptidae & Millipede & Archispirostreptus gigas & 23 & 32 & 55 & 11.00 \\
\hline \multirow{3}{*}{ Oligochaeta } & & & Unidentified & Unidentified & - & 1 & 1 & 0.20 \\
\hline & & & & Total & 130 & 370 & 500 & \\
\hline & & & & Percent (\%) & 26.00 & 74.00 & & 100 \\
\hline
\end{tabular}

$\mathrm{GF}=$ Gallery Forest

$\mathrm{RO}=$ Rocky Outcrop 


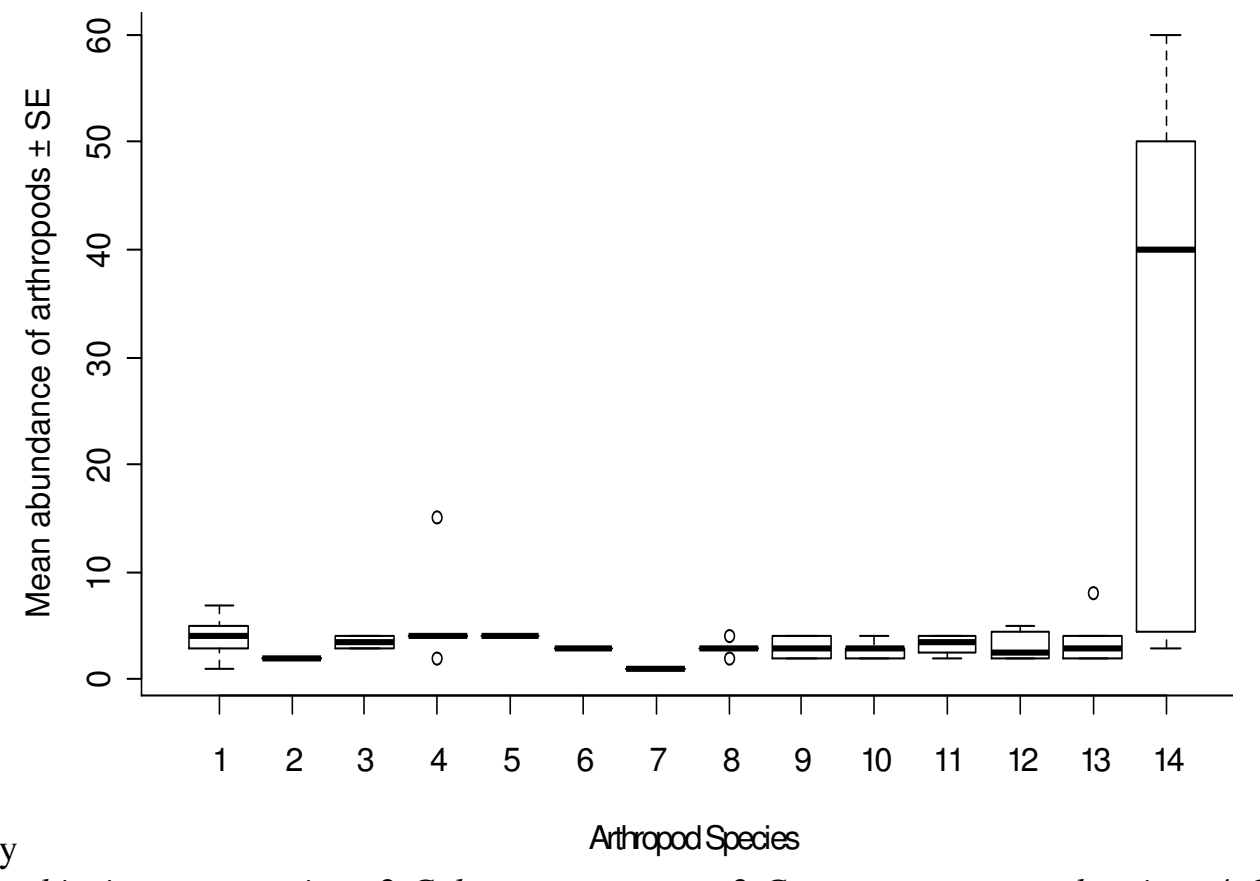

1.Archispirostreptus gigas 2.Calosoma scrutator 3.Camponotus pennsylvanicus 4.Cicindela ocellata 5.Corixa punctata 6.Grassiella wheeleri 7.Gryllus campestrus 8.Iridomyrmex purpureus 9.Paederus species 10.Loxosceles recluse 11.Lumbricus terrestris 12. Pholcus phalangoides 13.Scolopendra gigantean 14.Solenopsis invicta

Figure 1: Mean Species Abundance of Ground Dwelling Arthropods in the Jos Museum Zoological Garden

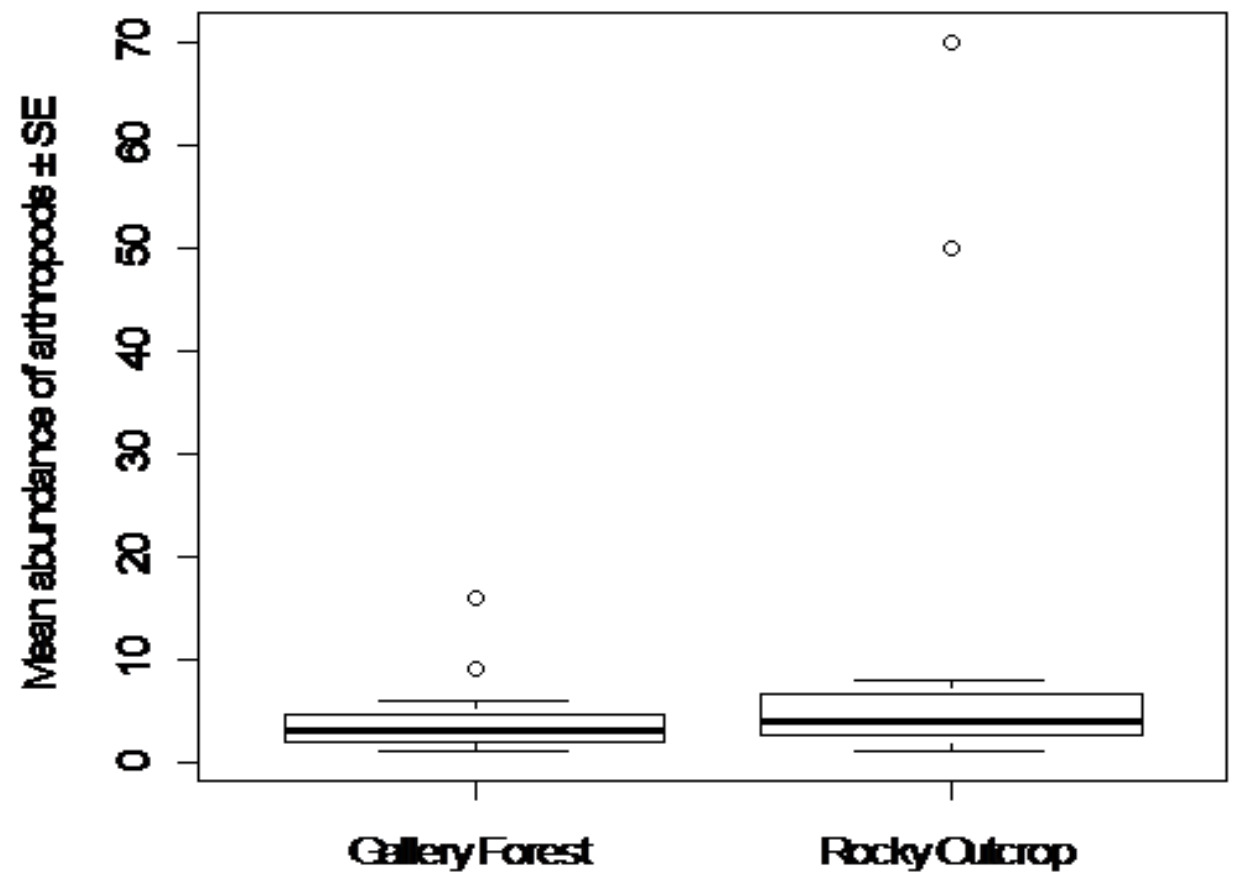

Habits

Figure 2: Comparison in Mean Abundance of Ground Dwelling Arthropods in Two Habitat Types of Jos Museum Zoological Garden 


\section{Abundance of Ground Dwelling Arthropods in Relation to Taxa}

There is no significant difference $\left(\mathrm{F}_{61}=1.039\right.$, Adjusted $\mathrm{R}$-squared $\left.=0.003, \mathrm{P}=0.4032\right)$ in the mean abundance of ground dwelling arthropods in relation to arthropod Classes in the Jos Museum Zoological Garden as shown in Figure 3.Arthropods collected in both habitats were identified as belonging to five (5) Classes of the phylum Arthropoda, Arachnida, Insecta, Chilopoda, Diplopoda and Oligochaeta. The Insecta recorded the highest abundance of 286 individuals representing 77.29\%, while Blatella lituricollis had the lowest abundance of 1 individual representing $0.77 \%$ (Figure 3 ).

There is no significant difference $\left(\mathrm{F}_{56}=1.527\right.$, Adjusted R-squared $\left.=0.074, \mathrm{P}=0.1542\right)$ in the mean abundance of ground dwelling arthropods in relation to arthropod Orders (Figure 4). The dominant orders identified in both habitats are Hymenoptera (5.00\%), Coleoptera $(5.20 \%)$ and Spirostreptida $(11.00 \%)$. While the least dominant orders are Thysanura $(2.31 \%)$, Orthoptera $(0.77 \%)$ and Blattodea $(0.77 \%)$ as shown in Figure 4.

\section{Species Diversity Index}

The species diversity, calculated as Shannon-Weiner Diversity Index $(\mathrm{H})$ differs significantly between different species in the two habitats investigated (Tables 2 and 3). The breakdown of the result revealed that the Gallery forest had the highest diversity index of 2.2140 and Rocky outcrop had the lowest diversity index of 0.9038 .

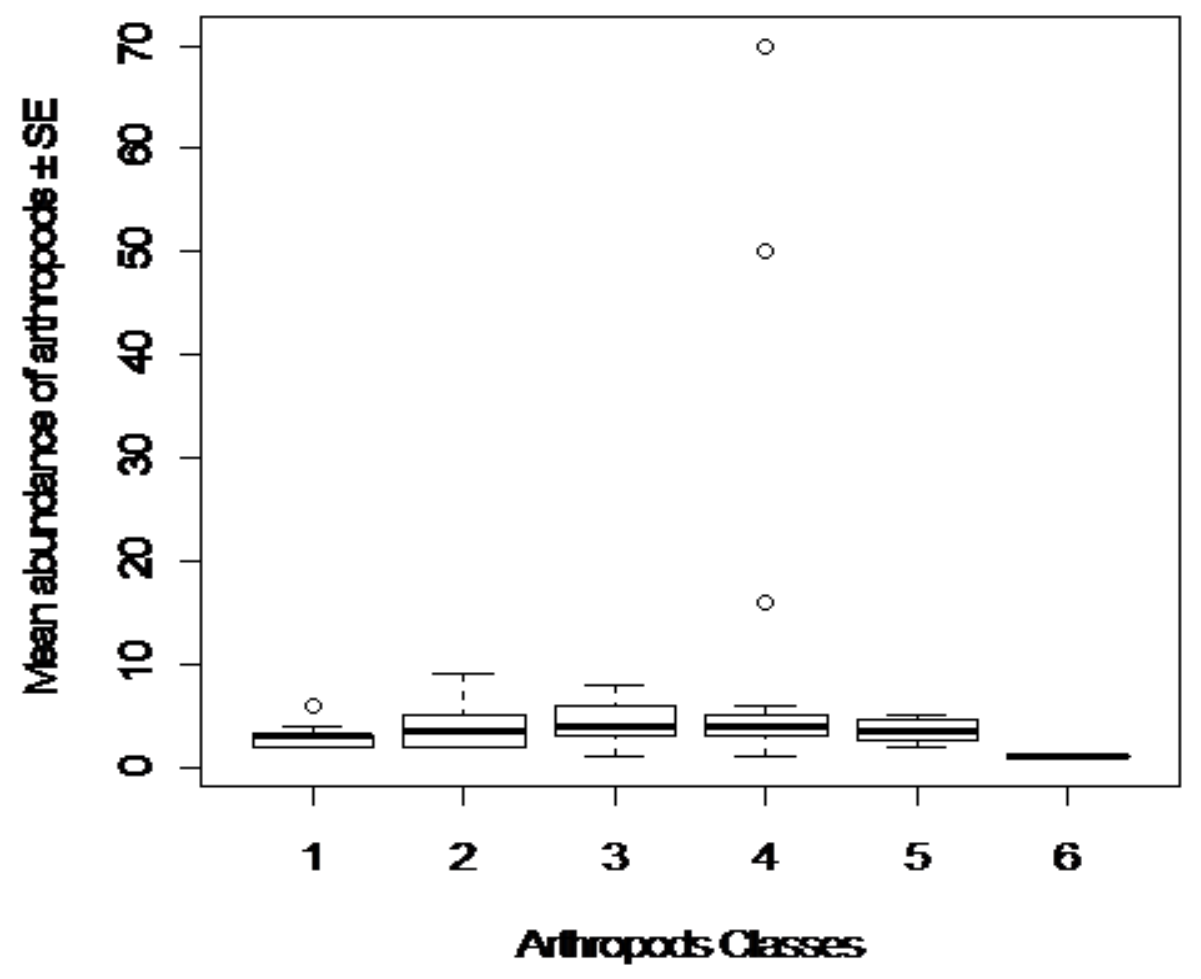

Key

1.Arachnida 2.Chilopoda 3.Diplopoda 4.Insecta 5. Oligochaeta 6. Unidentified

Figure 2: Mean Abundance of Ground Dwelling Arthropods in Relation to Classes 


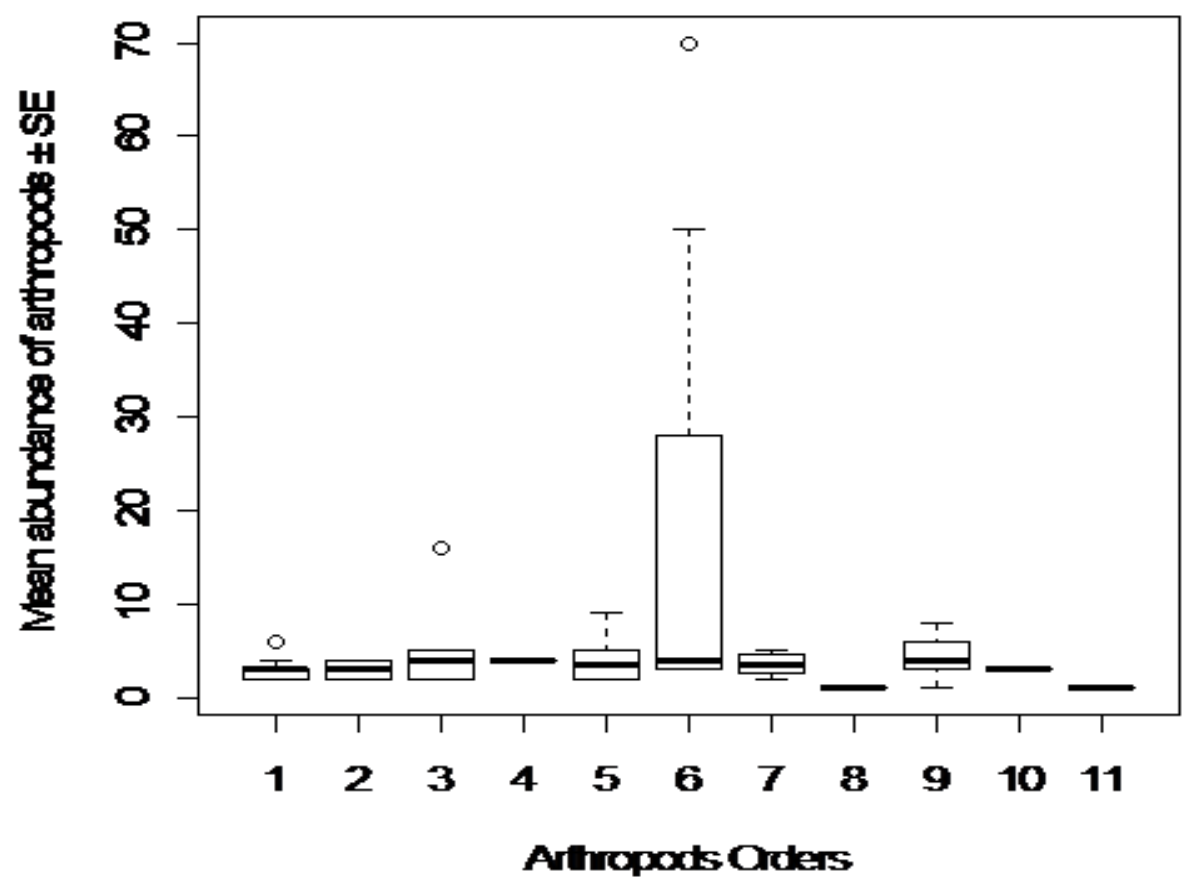

Key

1.Araneae 2.Blattodea 3.Coleoptera 4.Dermaptera 5.Geophilomorpha 6.Hymenoptera 7.Megadrilacea 8.Orthoptera 9.Spirostreptida10.Thysanura11.Unidentified

Figure 3: Mean Abundance of Ground Dwelling Arthropods In Relation to Orders

Table 2: Shannon- Weiner Diversity Index $(\mathrm{H})$ of Ground Dwelling Arthropods Trapped in Gallery Forest Jos Museum Zoological Garden

\begin{tabular}{lll}
\hline Species & Abundance & $\mathrm{H}$ \\
\hline Phalcus phalangoides & 15 & 0.2492 \\
Loxosceles reclusa & 17 & 0.2660 \\
Cicindella ocellata & 15 & 0.2492 \\
Iridomyrmex purpureus & 16 & 0.1974 \\
Camponotus pennsylvanicus & 3 & 0.0869 \\
Blatella lituricollis & 1 & 0.0374 \\
Corixa punctata & 4 & 0.1071 \\
Paederus species & 2 & 0.0642 \\
Gryllus campestus & 1 & 0.0374 \\
Grassiella wheerleri & 3 & 0.0869 \\
Scolopendra gigantea & 25 & 0.3170 \\
Archispirostreptus gigas & 23 & 0.3064 \\
Lumbricus terrestris & 11 & 0.2089 \\
\hline Total & 130 & 2.2140 \\
\hline
\end{tabular}


Table 3: Shannon- Weiner Diversity Index $(\mathrm{H})$ of Ground Dwelling Arthropods Trapped in Rocky Outcrop of Jos Museum Zoological Garden

\begin{tabular}{lll}
\hline Species & Abundance & H \\
\hline Phalcus phalangoides & 4 & 0.0490 \\
Loxosceles reclusa & 7 & 0.0752 \\
Iridomyrmex purpureus & 15 & 0.1301 \\
Solenopsis invicta & 286 & 0.1974 \\
Solenopsis molesta & 3 & 0.0391 \\
Blatella lituricollis & 4 & 0.0490 \\
Cicindella ocellata & 11 & 0.1047 \\
Calosoma scrutator & 2 & 0.0282 \\
Camponotus pennsylvanicus & 5 & 0.0582 \\
Archispirostreptus gigas & 23 & 0.1729 \\
unidentified & 1 & - \\
\hline Total & 370 & 0.9038 \\
\hline
\end{tabular}

\section{Discussions}

The health of an ecosystem is often measured by the biodiversity it holds, which is synonymous to its species abundance and diversity (Njila et al., 2013).The degree of species abundance and diversity of ground dwelling insects belonging to 6 Classes, 11 Orders, 12 Families, 14 Genera and 14 Species collected and identified in this study (Table 1) can be attributed to food availability and vegetation cover, which is consistent with the findings of Seastedt and Crossley (2004) working on the influence of arthropods on ecosystems reported that in the presence of abundant resources, arthropods population can grow at geometric or exponential rates and as the resources are depleted, the population growth rate slows and reproductive output by adults reduced.

The high abundance of Solenopsis invicta, Archispirostreptus gigas and Cicindella ocellata in this study is in agreement with the finding of Hickman $e t$ al. (2001) who reported high number of ants of the family Formicidae in a study carried out in Aldabra rain forest of India, where their dominance was linked to their Foraging and feeding habits. The ants (Solenopsis invicta) in this study are an important finding, these ants are known as important components of ecosystems because they act as ecosystem engineers (Folgarait, 1998).

The significant difference in the mean abundance of ground dwelling arthropods between the Gallery forest and Rocky outcrop of Jos Museum Zoological Garden (Figure 1) was attributed to differences in their habitat characterization. Though the abundance in the two habitats was high, it was significantly higher in the Rocky outcrop compared to the Gallery forest which was attributed to the presences of Ficus plant in the Rocky outcrop which attract so many insects that feed on its fruits example of insect order found within the plant is Hymenoptera. However low abundance in the Gallery forest was attributed to anthropogenic disturbances such as logging, livestock grazing and uncontrolled burning which may have contributed to the migration of arthropods from the Gallery forest to the Rocky outcrop. Such disturbances often produce a new set of challenges on the survival and reproduction of arthropods species that relay on vegetation to determine their foraging and breeding sites. This confirms the findings of Donald and Evans (2006) who worked on habitat connectivity and matrix were they revealed that arthropods generally preferred upslope area such as 
the Rocky outcrop due to disturbances by humans and other animals in the Gallery forest.

The diversity and distribution of the major taxa of arthropods in this study (Figures 3 and 4) depicted $73.00 \%$ Insecta and $64.40 \%$ Hymenoptera is consistent with the results of Molta et al. (1998) who also found Insecta and Hymenoptera as the most abundant taxa of insects on Acacia senegalensis in Hadejia-Nguru wetlands of north-eastern Nigeria.

The Gallery forest had the highest calculated Shannon-Weiner Index of 2.2140 and Rocky outcrop the least diversity Index of 0.9038 (Tables 2 and 3) thus confirming the report of Hughes et al. (2000), that species abundance and diversity differs with habitat types. The Shannon-Weiner Index in the Gallery forest and Rocky outcrop is a reflection of a relatively stable ecosystem in the Jos Museum Zoological garden which calls for intensification of conservation efforts.

\section{Conclusion}

The Jos Museum Zoological garden is highly rich in arthropods fauna considering the species diversity encountered in this study. The Garden is also unique as it is cited in a city surrounded by human settlement, a Phenomena uncommon to Nigeria cities. Food availability and vegetation cover was found to be critical for ground dwelling arthropods abundance and diversity in this study. This is a pointer to the usefulness of vegetation and food as key resources for ground dwelling arthropods.

\section{Recommendation}

It is widely accepted that the conservation of terrestrial biodiversity requires nature resources, which must be protected from unsustainable human activities. During this study one major problem observed in the Jos Museum
Zoological Garden are anthropogenic activities such as refuse dump, logging, grazing and bush burning. It is therefore recommended that adequate protection of the Garden should be carried out to curb these unsustainable human activities thereby allowing the arthropods to occupy their niche in the ecosystem.

\section{Acknowledgment}

The authors are very grateful to the staff of the Jos Museum Zoological Garden for their immense assistance.

\section{References}

Adebayo, C.O. (1995). Impacts of Land Uses on Biodiversity In: Impact of human activities on the West African Savanna. Proceedings of the Regional Training Workshop held at the Federal University of Technology, Akure, Nigeria.

Ajakpo, J.E. and Okonkwo, L.O. (1984). The Jos Plateau and the Adjoining Lowlands: A Field Guide 4th Edition, Department of Geography and Planning, University of Jos. 65pp

Basset, Y. (2001). Invertebrates in the canopy of tropical rainforest. How much do we really know? Plant Ecology, 153: 87-107.

Castner, J.L. (2000). Photographic Atlas of Entomology and Guide to insect Identification, Feline Press Gainesville U.S.A. Inc. pp.74-223.

Donald. P.F., and Evans, A.D. (2006). Habitat Connectivity and Matrix Restoration; the Wider Implication of Agric-Environment Scheme. Journal of Applied Ecology, 43: 209 - 218.

Folgarait, P.J. (1998). Ant Biodiversity and its Relationship to Ecosystem Functioning a review. Biodiversity and Conservation, 7: 1221- 1224.

Franke, B. (2003). Arthropods fauna of soils. Newsletter of the Biological 
survey of Canada. Terrestrial Arthropods 20 (2): 56-83.

Hickman, C.P., Roberts, L.S. and Larson, A. (2001). Integrated Principles of Zoology MC Graw Hill (1 $1^{\text {th }}$ Edition) pp. $173-195$.

Hughes, J.D., Daily, G.C and Ehrlich, P.R. (2000). Conservation of insect diversity: a habitat approach. Conservation Biology, 14(6): 17881797.

Molta, N.B., Buahin, G.K.A., Bdilya, H.H., and Akintrola, O.A. (1998). Insect species complex associated withAcaciasenegalensis in the Hadejia-Nguruwetlands of northeastern Nigeria. In: Lale, N.E.S, Molta, N.B., Donli, P.O., Dike, M.C. and Aminu Kano (Eds) Entomological Society of Nigeria Occassional Publication, 31:183186.

Motohiro, H. (2001). The relationship between the organic matter compositions of a Forest floor and the structure of a soil arthropod community. European Journal of Soil Biology, 37(4): 281-284.

Njila, H.L, Mwansat, G.S. and Imandeh, G.N. (2013).Species abundance and diversity of soil mites (Arachnida: Acari) along the bank of River Benue in Adamawa State, north-eastern Nigeria. Biological and Environmental Sciences Journal for the Tropics, 10 (4): 37-44.
Noss, R.F. (1990). Indicators for Monitoring Biodiversity: A Hierarchical Approach. The Journal of the society for conservation Biology, 4(4): 55- 361.

Seastedt, T.R. and Crossley, D.A. (2004).The influence of arthropods on ecosystems. Bioscience 34: 157161.

Shannon, C.E. and Weiner, W. (1963). A mathematical theory of communications. Bulletin of System Technology, 27: $379-423$.

Shattuck, S. O. (2000). Australian Ants, their Biology and Identification CSIRO Publishing $226 \mathrm{Pp}$.

Skaife, S.H., Ledger, J. and Bannister, A. (1979). African Insect Life New revised and Illustrated edition. pp. $253-355$.

Sutherland, W. J. (1997). Ecological Census Techniques. Cambridge University Press, Cambridge. 336 pp.

Thanukos, A (2007). The Arthropods story University of California. Berkeley. (http//evolution.Berkeley.edu/ evolibrary /article/ arthropod story).

Van den Bergh, E. (1992). Pitfall trapping invertebrates. Entomological News3:149 156.

Watt, A.D., Stork, N.E. and Bolton, B. (2002). The diversity and abundance of ants in relation to forest disturbance and plantation establishment in Southern Cameroon. Journal of Applied Ecology, 39(1): $18-30$. 